\title{
Defining Difference: The Role of Immigrant Generation and Race in American and British Immigration Studies
}

\section{Citation}

Waters, Mary C. 2014. Defining Difference: The Role of Immigrant Generation and Race in American and British Immigration Studies. Ethnic and Racial Studies 37, no. 1: 10-26.

\section{Published Version}

doi:10.1080/01419870.2013.808753

\section{Permanent link}

http://nrs.harvard.edu/urn-3:HUL.InstRepos:12872198

\section{Terms of Use}

This article was downloaded from Harvard University's DASH repository, and is made available under the terms and conditions applicable to Other Posted Material, as set forth at http:// nrs.harvard.edu/urn-3:HUL.InstRepos:dash.current.terms-of-use\#LAA

\section{Share Your Story}

The Harvard community has made this article openly available. Please share how this access benefits you. Submit a story.

Accessibility 


\title{
Mary C. Waters
}

\section{Harvard University}

\section{Defining Difference: The Role of Immigrant Generation and Race in American and British Immigration Studies}

\begin{abstract}
This article reviews the ways in which Britain and the U.S. classify and analyze the integration of immigrants and their descendants. While both societies recognize racial differences in their official statistics and in the academic analyses of change over time, the United States tends to classify immigrants and their descendants by immigrant generation much more than Britain does. The importance of the concept of generation in American immigration research is highlighted and it is suggested that studies built on the importance of generation can illuminate social processes of integration in Britain. The complexities of defining and measuring immigrant generation are reviewed, including new developments in the measurement of generation that take into account age at migration, and historical period and cohort effects. Racial and ethnic minority groups formed through immigration may have very different characteristics depending on the average distance of their members from immigration; including the possibility of "ethnic leakage", as later generation more assimilated individuals no longer identify with the group.
\end{abstract}

Keywords: generation, immigration, integration, assimilation, second-generation, race. 
While immigration is transforming most western democracies, scholarship documenting these changes cannot help but reflect the differing historical conditions that have shaped the destination countries where migrants settle. While the gap in scholarship on immigrant integration is converging between traditional countries of immigration such as the U.S., Canada and Australia and countries which have slowly come to terms with themselves as immigrant destinations-Western Europe and increasingly Southern Europe, there are still differences in empirical data available, theoretical models to guide research, and traditions within stratification research that influence the scholarship that is produced (Alba and Waters 2011). In this paper I describe how British and U.S. researchers have classified immigrant populations in their studies. I underscore the importance of generation in American immigration research and suggest that studies built on the importance of generation can illuminate social processes in Britain. I argue that immigrant integration can be obscured without careful attention to the measurement and theoretical specification of where and how generation matters to understanding immigrant integration. I then discuss some of the complexities of defining and measuring immigrant generation and I describe new developments in the measurement of generation that take into account age at migration, and historical period and cohort effects. These more refined definitions of immigrant generation would be a beneficial tool for both British and American researchers attempting to measure how well immigrants and their descendants are doing over time. 


\section{Historical Patterns of Immigration to the U.S. and the U.K.}

Comparative studies of immigrant integration in Europe and North America have stressed the ways in which the U.S. and the U.K. are more similar to one another than to other Western European countries on a number of dimensions important to understanding the pattern of immigrant integration. Britain and the U.S. have similar citizenship regimes (civic, not ethnic), similar welfare states and social benefits', similarly flexible educational systems that provide more opportunities for second chances and less early tracking into vocational education (especially when compared with other West European nations such as Germany and France), some overlaps in the national origins of immigrants (including sizable numbers of Caribbean blacks, Indians and Chinese) and similar attention to race as an important source of division in society (Loury, Modood and Teles 2005; Alba, Sloan and Sperling 2011).

The countries also have some important differences-a much longer and more prominent role for immigration in American history as opposed to British history, the presence of a large population of native African Americans in the U.S., the much greater role of Muslim immigrants in British society, the presence of the European Union in the British case, and the role of the long land border with Mexico and the large dominance of Latino immigrants in American immigration flows. Indeed the most pressing and complex immigration issue facing American society today is the presence of 11 million undocumented 
immigrants in the United States, approximately 7 million of whom are Mexicans. While Britain also has an undocumented population it is much smaller, both relatively and absolutely.

While the U.S. has been a magnet for immigrants from many different countries, Britain drew most of its immigrants in the latter half of the $20^{\text {th }}$ Century from former colonies. This colonial legacy was quite important in shaping expectations among immigrants of full inclusion in the society and in shaping the immigration laws and bureaucratic directives that allowed people into the country. It has also been important in shaping the statistical system that classifies the population leading to a system based more on measuring race and ethnicity rather than immigrant generation. In recent years Britain has begun receiving immigrants from Eastern Europe, especially Poland, and asylum seekers who may not come from former colonies, perhaps leading to different kinds of accommodation among immigrants in the future (Vertovec, 2007).

\section{Measurement of Race in the U.S. and U.K.}

It is the attention to race and the definition of groups as ethnic and racial minorities in both the U.S. and Britain that most differentiates them from other Western European countries coping with integration of immigrants and their descendants. The United States has classified post 1965 immigrants in racial terms, based on a system of classification and social identification that arose out of internal population dynamics owing to a long history of slavery and to the 
conquest of American Indians and Hispanics in the Southwest and Puerto Rico (Waters, 2008). When Asians started to arrive as immigrants in the late $19^{\text {th }}$ Century they were racially classified by the federal government and their racial exclusion was ultimately enshrined in American immigration law until the 1950s. In an ironic turn of events the classification of the population by race that had been developed in order to discriminate and exclude, was officially enshrined in our federal statistical system after the Civil Rights Movement resulted in legislation designed to prevent and prosecute discrimination, and is now most vigorously defended by racial minorities themselves.

The development of anti-discrimination legislation was also incorporated into British society. Modeled after the U.S. race and civil rights establishment, Britain has developed a policy based on multiculturalism and anti-racism to integrate immigrants and their descendants. Thus while Britain and the U.S. often perceive their "immigration" integration issues as race relations issues, this is very different from other Western European countries. France explicitly forbids collecting data on race and nationality and in Germany the sharp divisions that surround immigration are understood to be about birthplace, citizenship and ethnic belonging, rather than skin color. Yet this common language of race as an organizing principle of difference in Britain and the U.S. can obscure some real differences in what the two countries mean by "race" and in the social construction of ethnicity and in the drawing of group boundaries.

One possible difference between the U.S. and the U.K. has to do with the "color line" in both societies. In the U.S. there is a vigorous debate occurring 
about the key dividing line in American society. (Gans 1999; Foner and

Fredrickson 2004; Lee and Bean 2010). This debate centers on the question of whether the key division in American society is between whites on the one hand and non whites on the other, or whether the division is between blacks and nonblacks. In other words, the question is whether Asians and Latinos are being incorporated into American society onto the "white" or the "black" side of what W.E.B. Du Bois (1903) famously called "the color line". Before the Civil Rights movement and mass immigration from Asia, Latin America and the Caribbean, the position of Latinos and Asians was closer in many ways, even legally, to African Americans, than to whites. Recently, many scholars have argued that the high rates of intermarriage, residential integration of Asians and light skinned Latinos has meant that the serious ramifications of race for life chances in the US are concentrated among those socially identified as blacks, not those identified as non-whites. (Waters, 2008, Lee and Bean 2010, Kasinitz, 2004).

In the U.K., the key distinction might be more clearly drawn between white British and other non-whites. Patterns of acceptance and social identification continue to posit a common "minority" experience, encapsulated in the term BME or blacks and minority ethnics. In addition blacks are not uniformly more separate from whites than Asians are in Britain. Indeed on certain key indicators including intermarriage and residential integration black Caribbeans and black Africans are more integrated with whites than are Pakistanis and Bangladeshis (Peach 2005). This is very surprising to Americans who learn about it, since newly arrived immigrants from all over the globe quickly integrate with whites on 
these measures at higher levels than African Americans, despite their presence for hundreds of years, and their cultural similarities with native whites.

The U.S. does not have a flow of "white" European immigrants comparable to recent immigration to the U.K. The flow into Britain from elsewhere in Europe includes professional and highly educated workers from elsewhere in the European Union, as well as blue collar and unskilled workers from Eastern Europe. The non-professional workers moved into parts of the U.K., especially rural areas outside of the southeast near London and outside of the industrial northwest and midlands, that have not previously dealt with immigrants. In that sense these "new immigrant destinations" are similar to places in the American South and Midwest that have received large numbers of Latino immigrants in the last decade (Massey 2008). These new immigrant destinations also have no history of accommodating immigrants and they struggle with integration and diversity issues. In both countries language issues are at the forefront as well as the burdens on schools that have to accommodate new influxes of immigrant children. A key difference is that in the U.K. these new immigrants are white and in the U.S. Latinos are perceived as being racially different. No comparative research has yet been conducted on these new immigrant destinations in both countries but the similar shocks to rural areas and yet the different racial backgrounds of the immigrants would yield very interesting comparisons. Until now the official discourse in Britain has tended to focus on "visible", racial minorities, with the historical exception of the Irish of course, who were once a highly stigmatized group. Whether these low skilled European and 
white immigrants will come to be seen as a "problem" or as a "minority" remains to be seen.

\section{Models of Integration and Assimilation}

Comparative studies of immigration and ethnicity in the U.S. and Europe have become more numerous in recent years but the field is still in its very early stages. Two issues plague comparative research—different theoretical and analytical frameworks and a lack of comparable data and statistical definitions. Morawska $(2008 ; 2009)$ argues that scholars in the U.S. and Europe talk past each other in debating the usefulness of the concept of assimilation. American researchers widely use the term to refer to "a multiplace, multipath, contextdependent process of incorporation of immigrants and their offspring into the economic, civic-political, and social institutions and culture of different segments of the host society" (Morawska 2008:468). This modern concept of assimilation, fleshed out in detail in the major theoretical book by Alba and Nee (2003) is most decidedly a two way process in which immigrants change American society as well as being changed by it.

Yet European scholars continue to see the term assimilation in a negative way, interpreting it as it was used in the early $20^{\text {th }}$ Century as a one way requirement of immigrants that they "melt" into American society by giving up their ethnic distinctiveness. Morawska argues that European scholars often use 
the term "integration" to invoke the same process of mutual accommodation that American scholars refer to with assimilation.

In either case both European and American scholars have recognized the complex multicultural nature of the societies into which immigrants are assimilating. The American concept of "segmented assimilation" reflects this complexity. (Morawaska, 2008:470). This concept allows for the analysis of what parts of the host society immigrants and their descendants are joining. Portes and Zhou's (1993) theory of segmented assimilation asserts that immigrants can join the mainstream middle class, or can assimilate into a predominantly African American segment trapped in urban poverty and often referred to as the "underclass". They further argue that assimilation has been decoupled from mobility-assimilating into the host society might mean upward or downward social mobility over time.

Favell (2001) correctly argues that the nuts and bolts of empirical comparisons of how immigrants and their descendants are doing in European societies "must be related systematically back to the political construction of the problem in each country" Favell described the state of immigration research in Britain at the turn of the $21^{\text {st }}$ century as "significantly out of step with the rest of mainland Europe". This was because Britain had less large scale quantitative research on immigrants and their integration into the society, than other countries such as the Netherlands, Belgium, and Germany. The important OPCS volumes on ethnicity in the 1991 census ignored generational differences (with the important exception of Heath and McMahon who found that second generation 
ethnic minorities were significantly less likely to be employed in the "salariat"ii than their white British peers and thus suffered an "ethnic penalty" in the labor market.) ${ }^{i i i}$ (Heath and McMahon, 1996:91) The important series of studies sponsored by the Policy Studies Institute (PSI) (Daniel 1968, Smith 1977, Brown 1984 and Modood, Berthoud et al. 1997) only rarely mention generational differences-though the fourth PSI study does briefly look at generational differences.

Mostly though British quantitative research has focused on ethnic minorities, self identified using the categories developed for the census, without attention to generational change (Favell 2003). This developed out of the "conceptual history that has always looked for its normative inspiration to American race relations of the 1960s and has always defined Britain more narrowly as a country of post colonial immigration only."

\section{Data Availability: Census Categories in Both Countries}

The theories of immigrant assimilation developed in the U.S. during the twentieth century highlighted generational change as the yardstick to measure changes in immigrant groups. The first generation (the foreign-born) were less assimilated and less exposed to American life than were their American-born children (the second generation), and their grandchildren (the third generation) were in turn more like the core American mainstream than their parents. Empirically this generational progress was found for European origin groups for 
language, education, income, and residential assimilation and for patterns of intermarriage (Lieberson and Waters 1988; Alba, 1990).

Much of this research was possible because the American census which had always asked people where they were born also asked a birthplace of parents question from 1870 until 1970, and this information allowed researchers to track changes between the first and the second generation. These were the data by which legions of scholars documented changes in residence, language use, intermarriage, occupation and income from the immigrant generation to their native born children (Lieberson 1980). By 1980, the number of first and second generation European immigrants had dwindled and there was an interest in third and later generation ethnic groups. The birthplace of parents question was replaced with an ancestry question in 1980 so the ability to identify the second generation in census data was lost. Since the legacy of studying immigrant integration by generation was well established by the time post 1965 immigrants began to come of age scholars mounted studies to collect original data on the second generation to make up for the lack of census data (Portes and Rumbaut 2001; Kasinitz et. al. 2008; Bean et.al. 2010). In addition, the recognition that a new second generation was coming of age prompted the Current Population Survey (CPS) to add a birthplace of parents question in 1994. While the CPS is a large sample survey designed to measure employment variation by month, it does not have a large enough sample size to study the second generation by ethnic group with the exception of Mexican Americans who are numerous 
enough to analyze generational progress (Perlmann 2005; Smith 2003; Luthra and Waldinger 2010).

In Britain the long standing political concern with race mapped onto an academic concern with social class among social scientists working there. Social science research in the U.K. has had a strong tradition of documenting and explaining divisions in British society around social class. Thus British quantitative social science has been at the forefront of measuring social class and class mobility across generations (Goldthorpe, 1987). As the number of international migrants and their children increased in British society starting in the 1960 's scholars studying social class began to look at class mobility among ethnic and racial minorities alongside the white English. These studies of ethnic and racial disadvantage, and the class mobility of ethnic minorities discuss "ethnic penalties" owing to discrimination, but did not ordinarily look at generational progress or spheres beyond socioeconomic status. There has been much less attention to the classic questions of American immigration assimilation theory-generational change, and cultural and structural assimilation. This makes it difficult to ascertain if different trends exist by generation, or if the finding on ethnic minorities refer equally to the first, second and subsequent generations.

Most studies of Indians, Pakistanis, Bangladeshis, Chinese, BlackCaribbeans, and Black-Africans in Britain, until the 2000s had studied these ethnic minority groups largely as an undifferentiated mass, or decomposed them by the older and younger generation. The privileging of race and ethnicity as 
independent variables in mobility research in Britain meant that immigrants by generation over time had received less attention, although this has been changing in the last decade.

When survey and census data were not available to identify respondents by generational status the history of each ethnic minority, especially their periods of mass emigration and arrival into Britain helped in attempting to determine what proportion might be second generation, but this approach is not entirely satisfactory. The addition of birthplace and birthplace of parents questions in national statistics is necessary for documenting long term integration.

Fortunately, a number of studies have begun to introduce generation as an important variable and of course the present volume is a great step forward. There are some great resources for the study of ethnic minorities in Britain such as the 1993/1994 National Survey of Ethnic Minorities and the Millenium Cohort Study which has a significant over sample of ethnic minority groups

In addition to the lack of generational data in national statistics and the limits this has put on studies of the second generation, discussion of the second generation in both Britain and the U.S. has pointed to the context dependent nature of the theories that guide research. For instance, similar patterns of adaptation in schooling are clear in both Britain and the U.S. but Britain lacks the population of native born African Americans who are so important to the segmented assimilation theory (Warikoo 2011). So too, some scholars such as Kasinitz and colleagues (2008) have pointed to the role of affirmative action programs to explain the educational success of the second generation in the US. 
Britain does not have such a program yet does seem to have similar patterns of educational mobility for the second generation. It remains to be seen whether the existence of an ethnic penalty in Britain is in part due to the absence of affirmative action type policies.

\section{The Concept of Generation and its Measurement}

The experience of European immigrants in the U.S. in the twentieth century was sharply defined by the cutoff in immigration that occurred as a result of the Depression and the restrictive immigration laws of the 1920s. This restriction created conditions that made generation a powerful variable. Not only did one's generation define one's distance from immigrant ancestors, but it also served as a proxy for birth cohort and for distance from all first-generation immigrants. The power of generation as an independent variable predicting degree of assimilation was tied, in ways few social scientists recognized, to the specific history of the flows of immigration from Europe. Restrictive laws passed in 1924 and the Great Depression largely ensured the halt of large-scale immigration from Europe to the United States. Thus, major studies examined the experience of immigrants and their descendants as they became Americans in a society absent of any significant immigrant replenishment. Each successive generation and cohort born in the United States had less contact with immigrants, attenuating the salience of ethnicity in their lives (Alba 1990, Waters 1990). 
For European immigrants to the U.S. the "generation" served as a temporal gauge of immigrant group assimilation, where "generation" is the ancestral distance from the point of arrival in a society (Alba 1988, p. 213). Using generation as a temporal gauge makes sense when examining the experiences of groups for which there is no protracted immigrant replenishment, as in research done on the immigrants and descendents of the Great European Migration. Each successive generation born in the United States had less contact with an immigrant generation, both within and outside of the family, precisely because there was no significant replenishment from European countries when those groups were studied. An additional reason for using generation is that there was a high correlation between the generation of these European-origin individuals and their birth cohorts. Because many European groups immigrated during a compressed period of time, older individuals tended to be of earlier generation (i.e., first and second), whereas younger people were from later generations (i.e. third and fourth). Thus, each generation of European-origin individuals also experienced American society as a birth cohort, i.e., a group of people who experience fluctuations in life chances and constraints at roughly the same point in their life cycle.

These assumptions about generation are invalid when there is ongoing immigrant replenishment, as there is now, because at any point in time each generation is a mix of cohorts and each cohort has a mix of generations. Individuals from different generations but of the same birth cohort, then, may experience similar shifts in life chances that society offers (because they are in 
the same birth cohort), even if they experience a different dynamic internal to the ethnic group (because they are from different generations). As Alba (1988:214) notes, "[T]he generational perspective tends to deflect attention from the structural basis of ethnicity, the linkage between ethnic group and the economy and the polity of the larger society, and to focus instead on the internal dynamic of change".

This observation of the American case also applies to many groups in Britain. While much immigration, especially the East African Asian migration for example, was quite concentrated in time, there has been continual replenishment especially for Pakistani and Bangladeshis groups because of 'family reunion' (often arranged marriages with new migrants from the home country). The division of respondents by generation may be much sharper and more socially relevant therefore for some groups than for others. The case of Mexican Americans might be especially relevant for groups such as British Pakistanis and British Bangladeshis who have mixed generational households.

Using generation also sometimes homogenizes an immigrant generation that comes from sending countries that are very different over time. While both a newly arrived 18 year old Pakistani arriving in Britain to attend university in 2012 and an 80 year old who left Pakistan soon after its creation in 1947 would both be classified as "first generation", the Pakistan they left behind is quite a different society and the Pakistani identity and culture they carry with them reflects these changes. They are of the same "immigrant generation" but very different historical generations. 
In a landmark study of generational change among Mexican Americans, Telles and Ortiz (2008) recognize that generation for a group like Mexicans with a long continous history of immigration can be measured in a number of ways. They distinguish between generation-since-immigration, and family generation. Because they have a longitudinal study which began in the 1960s with different generations of Mexican Americans, they can look at change over generations since immigration, as well as changes within families-from grandparents to parents to children. In some cases the original grandparents in the 1960 s study were themselves second generation. Thus they show family generational progress over time-from grandfather to father to son, as well as documenting stalled progress for Mexican American third generation respondents who do not show convergence with native whites.

In a reanalysis of these data Alba, Jimenez and Marrow (2013) argue that it is important to think about the different historical periods that current Mexican second generation people lived through. The current Mexican second generation includes older people who grew up in a segregated society in the 1920s and 30s where de jure discrimination against Mexicans was practiced, and young people who came of age in a post industrial, affirmative action era where de jure but certainly not de facto discrimination had ended. They argue that intermarriage and mixed ancestry characterize later generations of Mexican Americans, and if those more assimilated later generation respondents are not captured in surveys, the relative success of the group might be underestimated. This is because there is a link between higher educational attainment, mixed ancestry. 
intermarriage and geographic mobility" (Alba, Jimenez and Marrow 2013:19). Duncan and Trejo (2011) and Alba and Islam (2009) find that this "ethnic leakage" of the children or grandchildren of Mexican immigrants who are better educated and more likely to be intermarried no longer identifying as Mexican or Hispanic at all can lead to large differences in the characteristics of the Mexican American population (see also Emeka and Agius Vallejo 2011). These successful and often intermarried later generation Mexican Americans disappear into the native white category, and the later generation Mexican group who continue to identify as Mexican appear less successful than they actually are.

Qualitative studies have also found that there are many choices occurring among the descendants of immigrants about how much to identify with different ancestries, with strong evidence that these choices may bias quantitative estimates of social stratification and assimilation (Waters 1999; Jimenez 2010; Agius Vallejo 2012).

This process of ethnic decline through identity choices could also explain the diverging demographics of the descendants of Irish immigrants in the U.S. vs. Britain. Irish was added to the 2001 census after the Commission for Racial Equality in the mid 1990's recommended the inclusion of the Irish in ethnic monitoring and issued a report documenting discrimination against the Irish. The number of people choosing to identify as White-Irish on the British census is much smaller than what one would expect given the large numbers of migrants to Britain from Ireland in the post World War II period. Most of those who chose White-Irish were first generation immigrants_people born in Ireland. Thus many 
second, third and later generation people of Irish ancestry in Britain no longer identify as Irish, at least in the census.

In the U.S. the census does not allow people to identify as Irish on the race question but the ancestry question does allow people to state their ethnic ancestry in an open-ended question. The "stickiness" of Irish identity is quite evident as Irish is a wildly popular identity (Waters 1990; Alba 1990). Hout and Goldstein (1994) analyzed these data and found many more people identifying as Irish on the 1990 American census than one would expect given historical numbers of immigrants and natural increase. Their article, entitled "How 4.5 million Irish Immigrants came to be 41 million Irish Americans" argued that the large number of people identifying as Irish was due to the offspring of intermarriages between Irish and non Irish disproportionately claiming Irish as their identity. While both the U.S. and Britain have histories of anti-Irish discrimination, it is a distant and often forgotten memory in the U.S. and whereas it is more salient and recent history in Britain—especially in Northern Ireland of course where there remains a major issue of Catholic disadvantage and prejudice, as well as in Scotland where there is also some evidence of ongoing, albeit declining, anti-Catholic prejudice. (On Northern Ireland see Li and O'Leary 2007; on Scotland see Abbotts et al 2004.)

In Britain where the Afro Caribbean population has high levels of partnering (if not always formal marriage) with whites this process might also be progressing. In later generations with more intermixing, when does an individual 
no longer identify as "mixed" on the census and is that related to socioeconomic characteristics? Would a generational approach to all of the ethnic and minority groups in Britain show some of this "ethnic leakage" into the mainstream white population? A recent study by Muttarak and Heath (2010) find that intermarriage increases in the second generation for all groups in Britain, even those who are known to be more endogamous than other groups (Indians, Pakistanis and Bangladeshis.) They also find that for some groups such as the Indians, the higher the education the more likely the individual will outmarry. This implies that over a few generations there could be significant ethnic demographic loss of identity such as that observed among Mexicans in the US.

Another important strand of research in the U.S. has examined the intersection of lifecourse and age at migration with generational measures for the first generation. The research on the second generation in recent decades has not followed a consistent pattern in identifying the children of immigrants. Many studies such as the Children of Immigrants Longitudinal Study and the New York Second Generation Study have included in the "second generation", children born abroad of immigrant parents who immigrated in childhood (Kasinitz et.al. 2008; Portes and Rumbaut 2001). Because of the limitations of census data described above, Perlmann (2005) for instance uses arrival at very young ages as a proxy for the second generation in his study of Mexican Americans. Rumbaut (2004) coined the term 1.5 generation and further described the fractional 1.25 and 1.75 generation to describe children who came before formal schooling at age 6 (1.75 generation), and those who came after age 12 but 
before age 18 as the 1.25 generation. He defined children who came between 6 and 12 as the 1.5 generation. This division made theoretical sense, as it divided children into categories based on their exposure to the host country-the 1.75 generation had all their formal schooling in the host country, the 1.5 generation arrived in middle childhood, and the 1.25 generation arrived in adolescence, when most of them would never learn to speak the host language without an accent and at a time in which some patterns of beliefs and behaviors have become set.

While some sociologists have used Rumbaut's classification, there has been no agreed upon definition of where the cut off points should be. Myers, Gao and Ameka (2009) note that without a strong tradition of classification, different methods have proliferated. They note that "sociologists have treated 1.5ers as late arriving members of the second generation. Economists have treated them as early arriving members of the first generation".

Two recent American studies have investigated whether a continuous or categorical measurement of age at arrival is a better approach for assessing its impact on different dimensions of assimilation. Myers, Gao and Ameka (2009) examined this question for Latinos and Lee and Edmonston (2011) examined it for Asians. Both analyses show that using years since immigration or a continuous measure for "exposure" to the host society was most accurate. They both did not find much support for the threefold categorization proposed by Rumbaut (2004). For Latinos, Myers and colleagues suggest splitting the population into people who arrived before age 6 , between 6 and 9, between 10 
and 12, and between 13 and 17. Lee and Edmonston (2011) recommend a split at 5, 9 and 12. Both analyses find strong effects on host country language attainment and educational attainment for age at arrival. For Latinos, "immigrants who arrive prior to the age of six are six times as likely to complete high school and nearly 14 times as likely to speak English very well in adulthood compared to Mexican immigrants who arrive as teens." (Myers, Gao and Ameka 2009:225). Age at arrival is similarly important in affecting language and educational attainment among Asians. Lee and Edmonston caution that since immigrant groups differ in age at arrival, these compositional effects are driving some of the differences in these outcome variables across groups. (Lee and Edmonston 2011:557).

Heath and Kilpi-Jakonen (forthcoming) have examined the effects of age at arrival on educational outcomes in OECD countries using PISA data. They find that there is a "late arrival penalty" for educational achievement where late arriving children do worse than early arriving children. But they also find that there is no cutoff age that best captures this effect. Instead of a categorical approach they suggest that the log of the years in the destination country works best in predicting host country language attainment. This echoes the work of Myers Gao and Ameka (2009) that a continuous measure is best for capturing age of arrival effects.

\section{Conclusion}


A simple categorization of the immigrant population by generation yielded a great deal of evidence of patterns of assimilation for European ethnic groups in the $20^{\text {th }}$ Century in the U.S. The children and grandchildren of the post 1965 immigrants are also influenced by generational change, intersecting with their racial classification as Latino, Asian, Black or White. In addition, recent research has pointed to three modifications to the concept of generation, given the more complex relationship of age period and cohort in current immigration as compared with European immigrants and their descendants in the first half of the $20^{\text {th }}$ Century.

First, researchers should be careful about the use of synthetic cohorts from cross-sectional data on immigrant generation to infer patterns of assimilation. When historical cohorts face very different societal receptions (as is the case with Mexican Americans), the experience of the elderly second generation surveyed today may be very different than the experience of the second generation who are now schoolchildren when they are surveyed when they are older. Historical cohorts as well as cross sectional cohorts, or as Telles and Ortiz (2008) state, "family generation", as well as "generation-sinceimmigration" should be measured and distinguished.

Second, researchers should check for or be aware of "ethnic identity leakage". Over one or two generations it is likely that the best educated, most socially and geographically mobile people are most likely to intermarry and have mixed ancestry children. By the third or fourth generation these descendants could change their identities and disappear statistically from the group. This 
would bias generational measures of assimilation or integration if the "missing" ethnic group members share social and economic characteristics with each other that are different from the characteristics of those who stay identified with the group.

Third, since children develop rapidly, and in country schooling and the ability to learn the host country language without an accent differs by age at arrival, the experience of the children of immigrants is likely to differ by this important variable. The fractional generation categories of 1.25 , or 1.5 or 1.75 can be employed if that is all that is available, but a continuous measure of age at arrival is even better at capturing this effect. Recent work suggests that care should be used in choosing these cutoff points, and that they be related to the dimension of assimilation that will be measured.

The American scholarly literature on assimilation of immigrants and their children most definitely shows that on many dimensions change occurs over the course of several generations. Descendants of Afro Caribbeans in the U.K. are mostly third and fourth generation at this time. Many Asian groups are second and third generation, and new groups from Eastern Europe are primarily first generation. In addition to the rich data on social class and self identification that have been analyzed, a moving picture of British integration should include generational changes over time.

MARY C. WATERS is M.E. Zukerman Professor of Sociology at Harvard University. 
ADDRESS: Department of Sociology, 540 William James, 33 Kirkland Street, Harvard University, Cambridge, MA 02138.

Email: mcw@wjh.harvard.edu 
References

ABBOTTS, J., WILLIAMS, R., WEST, P., HUNT, K. \& FORD, G. 2004 'Catholic socio-economic disadvantage in the West of Scotland: a narrowing of inequality', Scottish Affairs, vol. 24, pp. 77-87.

AGIUS VALLEJO, J. 2012. Barrios to Burbs: The Making of the MexicanAmerican Middle Class. Stanford: Stanford University Press.

ALBA, R. 1988 'Cohorts and the Dynamics of Ethnic Change', in RILEY, M. W. (ed) Social Structure and Human Lives. Newbury Park, CA: Sage.

--- 1990 Ethnic Identity: The Transformation of White America. New Haven: Yale University Press.

ALBA, R. \& ISLAM, T. 2009 'The case of the disappearing Mexican Americans: An ethnic-identity mystery', Population Research and Policy Review, vol. 28, pp. 109-121.

ALBA, R., JIMENEZ, T. \& MARROW, H. 2013 'Mexican Americans as a Paradigm for Contemporary Intragroup Heterogeneity', forthcoming Ethnic and Racial Studies.

ALBA, R., SLOAN, J. \& SPERLING, J. 2011 'The Integration Imperative: The Children of Low-Status Immigrants in the Schools of Wealthy Societies', Annual Review of Sociology, vol. 37, pp. 395-416.

ALBA, R. \& WATERS, M. C. 2011 'The Next Generation: Immigrant Youth in Comparative Perspective'. New York: New York University Press.

ALBA, R. D. \& NEE, V. 2003 Remaking the American Mainstream: Assimilation and Contemporary Immigration. Cambridge, MA: Harvard University Press.

BEAN, F. D., LEACH, M. A., BROWN, S. K., BACHMEIER, J. D. \& HIPP, J. R. 2011 'The Educational Legacy of Unauthorized Immigration', International Migration Review, vol. 45, no. 2, pp. 348-385.

BROWN, C. 1984. Black and White Britain: the third PSI survey. London: Heinemann.

DANIEL, W.W. 1968 Racial Discrimination in England. London: Penguin.

DUNCAN, B. \& TREJO, S. J. 2011 'Tracking the Intergenerational Progress for Immigrant Groups: The Problem of Ethnic Attrition', American Economic Review: Papers and Proceedings, vol. 101, no. 3, pp. 603-608.

EMEKA, A. \& AGIUS VALLEJO J. 2011. 'Non-Hispanics with Latin American ancestry: Assimilation, race, and identity among Latin American descendants in the U.S.' Social Science Research vol. 40 pp. 1547-1563.

FAVELL, A. 2001 'Integration policy and integration research in Europe: a review and critique', in ALEINIKOFF, T. A. \& KLUSYMEYER, D. (eds) Citizenship Today: Global Perspetives and Practices. Washington DC: Brookings 
Institute/Carnegie Endowment for International Peace.

--- 2003 'Integration Nations: The Nation State and Research on Immigrants in Western Europe', Comparative Social Research, vol. 22, no. October, pp. 211-228.

FONER, N. \& FREDRICKSON, G. M. 2004 'Not Just Black and White: Historical and Contemporary Perspectives on Immigration, Race and Ethnicity in the United States'. New York: Russell Sage Foundation.

GANS, H. 1999 'The Possibility of a New Racial Hierarchy in the Twenty-First Century United States', in LAMONT, M. (ed) The Cultural Territories of Race: Black and White Boundaries Chicago: University of Chicago Press.

GOLDTHORPE, J. H. 1987 Social Mobility and Class Structure in Modern Britain. Oxford: Clarendon Press.

HEATH, A. \& MCMAHON, D. 1996 'Education and Occupational Attainments: The Impact of Ethnic Origins ', in KARN, V. (ed) Ethnicity in the 1991 Census Office for National Statistics.

HEATH, A. \& KILPI-JAKONEN, E. Forthcoming. 'Immigrant children's age at arrival and assessment results. OECD working paper.

HOUT, M. \& GOLDSTEIN, J. 1994 'How 4.5 million Irish Immigrants Came to Be 41 Million Irish Americans: Demographic, Social and Subjective Components of the Ethnic Composition of the White Population of the United States', American Sociological Review, vol. 59, pp. 64-82.

JIMENEZ, T. R. 2010 Replenished Ethnicity: Mexican Americans, Immigration and Identity. Berkeley: University of California Press.

KASINITZ, P. 2004 'Race, Assimilation and Second Generations: Past and Present', in FONER, N. \& FREDRICKSON, G. M. (eds) Not Just Black and White: Historical and Contemporary Perspectives on Immigration, Race, and Ethnicity in the United States. New York: Russell Sage Foundation.

KASINITZ, P., MOLLENKOPF, J., WATERS, M. C. \& HOLDAWAY, J. 2008 Inheriting the City: The Children of Immigrants Come of Age. Cambridge and New York: Harvard University Press and Russell Sage Foundation.

LEE, J. \& BEAN, F. 2010 The Diversity Paradox: Immigration and the Color Line in Twenty First Century America. New York: Russell Sage Foundation.

LEE, S. \& EDMONSTON, B. 2011 'Age-at-Arrival's Effects on Asian Immigrants' Socioeconomic Outcomes in Canada and the U.S.', International Migration Review, vol. 45, no. 3 (Fall), pp. 527-561.

LI, Y. \& O'LEARY, R. 2007. 'Progress in reducing Catholic disadvantage in Northern Ireland'. Proceedings of the British Academy, vol. 137, pp. 551589.

LIEBERSON, S. 1980 A Piece of the Pie: Blacks and White Immigrants Since 1880. Berkeley: University of California Press.

LIEBERSON, S. \& WATERS, M. C. 1988 From Many Strands: Ethnic and Racial Groups in Contemporary America. New York: Russell Sage Foundation.

LOURY, G. C., MODOOD, T. \& TELES, S. M. 2005 'Ethnicity, Social Mobility and Public Policy; Comapring the US and the UK'. Cambridge: Cambridge University Press.

LUTHRA, R. \& WALDINGER, R. 2010 'Into the Mainstream? Labor Market 
Outcomes of Mexican Origin Workers', International Migration Review, vol. 44, no. 4 Winter, pp. 830-868.

MASSEY, D. S. 2008 'New Faces in New Places: The Changing Geography of American Immigration'. New York: Russell Sage Foundation.

MODOOD, T. \& BERTHOUD, R. 1997 Ethnic Minorities in Britain: Diversity and Disadvantage. London: Policy Studies Institute.

MORAWKSA, E. 2008 'Research on Immigration/Ethnicity in Europe and the United States: A Comparison', The Sociological Quarterly, vol. 49, no. 3, pp. 465-482.

MORAWSKA, E. 2009 A Sociology of Immigration: (Re)Making Multifaceted America. New York: Palgrave Macmillan.

MUTTARAK, R. \& HEATH, A. 2010 'Who intermarries in Britain? Explaining Ethnic Diversity in Intermarriage Patterns', British Journal of Sociology, vol. 61, no. 2, pp. 275-305.

MYERS, D., GAO, X. \& EMEKA, A. 2009 'The Gradient of Immigrant Age-atArrival Effects on Socioeconomic Outcomes in the U.S.', International Migration Review, vol. 43, no. 1 (Spring), pp. 205-229.

PEACH, C. 2005 'Social Integration and Social Mobility: Spatial Segregation and Intermarriageof the Caribbean Population in Britain', in LOURY, G. C., MODOOD, T. \& TELES, S. M. (eds) Ethnicity, Social Mobility, and Public Policy. . Cambridge: Cambridge University Press.

PERLMANN, J. 2005 Italians Then, Mexicans Now: Immigrant Origins and Second-Generation Progress, 1890 to 2000. New York City: Russell Sage Foundation.

PORTES, A. \& RUMBAUT, R. 2001 Legacies: The Story of the Immigrant Second Generation. Berkeley and Los Angeles; New York University of California Press; Russell Sage Foundation

PORTES, A. \& ZHOU, M. 1993 'The New Second Generation: Segmented Assimilation and Its Variants among Post-1965 Immigrant Youth', Annals of the American Academy of Political and Social Science, vol. 530, pp. 74-96.

RUMBAUT, R. 2004 'Ages, Life Stages and Generational Cohorts: Decomposing the Immigrant First and Second Generations in the United States', International Migration Review, vol. 38, no. 3, pp. 1160-1205.

SMITH, D. 1977 Racial Disadvantage in Britain. London: Penguin.

SMITH, J. 2003 'Assimilation Across the Latino Generations', American Economic Review, vol. 93, no. 2, pp. 315-319.

TELLES, E. \& ORTIZ, V. 2008 Generations of Exclusion: Mexican Americans, Assimilation and Race. New York: Russell Sage Foundation.

VERTOVEC, S. 2007 'New Complexities of Cohesion in Britain: Super Diversity, Transnationalism and Civil-Integration'. Commission on Integration and Cohesion.

WARIKOO, N. 2011 Balancing Acts: Youth Culture in the Global City. Berkeley: University of California Press.

WATERS, M. C. 1990 Ethnic Options: Choosing Identities in America. Berkeley: University of California Press. 
--- 1999 Black Identities: West Indian Immigrant Dreams and American Realities Cambridge: Harvard University Press.

--- 2008 'Counting and Classifying by Race: The American Debate', The Tocqueville Review, vol. XXIX, no. 1, pp. 1-21.

ZHOU, M. 1997 'Segmented Assimilation: Issues, Controversies, and Recent Research on the New Second Generation', International Migration Review, vol. 31, no. 4 (Special Issue), pp. 975-1008.

${ }^{i}$ Britain is still more generous than the US but the two countries are much less generous than established European welfare systems.

i" "The salariat or service class consists of salaried employees such as managers, administrators, or professionals, have relatively secure employment, an incremental salary scale, fringe benefits (e.g pension schemes), and significant promotion chances" Heath and McMahon (1996:92).

iii Their analysis excluded second generation Chinese and Bangladeshis because of negligible numbers. 